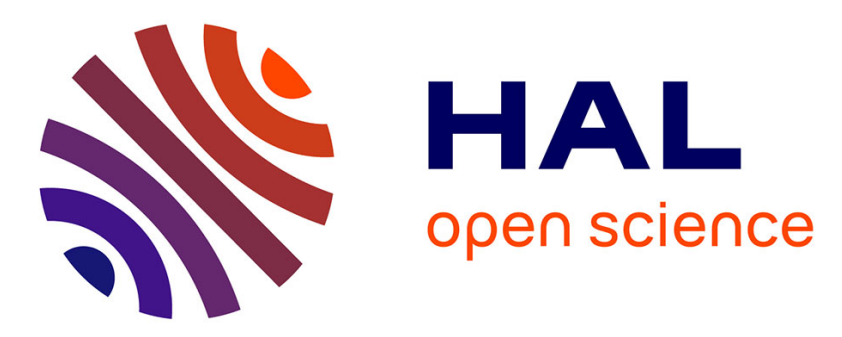

\title{
Effect of electro discharge machining (EDM) on the AISI316L SS white layer microstructure and corrosion resistance
}

Habib Sidhom, Farhat Ghanem, Tidiane Amadou, Gonzalo Gonzalez, Chedly Braham

\section{- To cite this version:}

Habib Sidhom, Farhat Ghanem, Tidiane Amadou, Gonzalo Gonzalez, Chedly Braham. Effect of electro discharge machining (EDM) on the AISI316L SS white layer microstructure and corrosion resistance. International Journal of Advanced Manufacturing Technology, 2013, 65 (1-4), pp.141-153. 10.1007/s00170-012-4156-6 . hal-00994534

\section{HAL Id: hal-00994534 https://hal.science/hal-00994534}

Submitted on 21 May 2014

HAL is a multi-disciplinary open access archive for the deposit and dissemination of scientific research documents, whether they are published or not. The documents may come from teaching and research institutions in France or abroad, or from public or private research centers.
L'archive ouverte pluridisciplinaire HAL, est destinée au dépôt et à la diffusion de documents scientifiques de niveau recherche, publiés ou non, émanant des établissements d'enseignement et de recherche français ou étrangers, des laboratoires publics ou privés. 


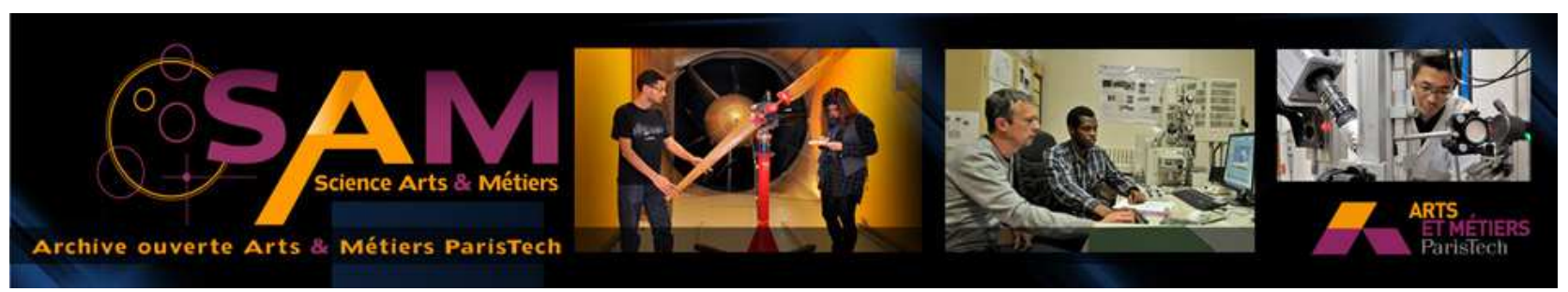

\section{Science Arts \& Métiers (SAM)}

is an open access repository that collects the work of Arts et Métiers ParisTech researchers and makes it freely available over the web where possible.

This is an author-deposited version published in: http://sam.ensam.eu

Handle ID: .http://hdl.handle.net/10985/8176

\section{To cite this version :}

Habib SIDHOM, Farhat GHANEM, Tidiane AMADOU, Gonzalo GONZALEZ, Chedly BRAHAM Effect of electro discharge machining (EDM) on the AISI316L SS white layer microstructure and corrosion resistance - The International Journal of Advanced Manufacturing Technology - Vol. 65, $n^{\circ} 1-4$, p.141-153 - 2013 


\title{
Effect of electro discharge machining (EDM) on the AISI316L SS white layer microstructure and corrosion resistance
}

\author{
Habib Sidhom • Farhat Ghanem • Tidiane Amadou • \\ Gonzalo Gonzalez • Chedly Braham
}

\begin{abstract}
The localised corrosion resistance of austenitic stainless steels is strongly influenced by the quality of finished surface. EDM machining induces substantial changes by the high thermal gradients generated by electric sparks. Experimental techniques such as roughness measurement, scanning electron microscopy (SEM), energy dispersive microanalysis (EDX) and X-ray diffraction technique, reveal microgeometrical, microstructural, chemical and mechanical changes. These changes lead to white and heat-affected layers with a depth less than $100 \mu \mathrm{m}$. The white layer is a melted material characterised by dendritic structure and constituted by austenite, chromium carbide and $\varepsilon$-carbide. The heat-affected layer is characterised by very large grain size comparatively to the bulk material. Electrochemical test coupled with metallographic examinations using SEM reveals a weakening of the resistance to pitting and intergranular corrosion comparatively to diamond polished surface. This weakening is correlated to differences in structure and chemical composition of white layer. Susceptibility to stress corrosion cracking has been
\end{abstract}

\author{
H. Sidhom · F. Ghanem · T. Amadou \\ Laboratoire de Mécanique Matériaux et Procédés, \\ ESSTT-Université de Tunis, \\ 5 Av. Taha Hussein, \\ 1008 Montfleury, Tunisia \\ G. Gonzalez \\ Instituto de Investigaciones en Materiales, Universidad Nacional \\ Autónoma de México, Circuito Exterior S/N, Cd. Universitaria, \\ A.P. $70-360$, \\ Coyoacán, \\ 04360 México, D. F., Mexico \\ C. Braham $(\square)$ \\ PIMM, CNRS UMR 8006, Arts et Métiers ParisTech, \\ 151, Bd de l'Hôpital, \\ 75013 Paris, France \\ e-mail: chedly.braham@ensam.eu
}

attributed to the field of tensile residual stresses resulting from thermal effects. The removal of the white layer material by polishing or wire brushing restores the corrosion resistance of the AISI316L SS.

Keywords EDM · Corrosion - Surface · Microstructure · White layer · Residual stress

\section{Introduction}

The complex part shapes in metallic carbides or high strength steels are usually manufactured by high energy density processes like electron beam, laser or electric discharge machining (EDM) [1-3]. The main advantage of these processes is the low dimensional dispersion comparatively to conventional machining process. This high accuracy results from the absence of physical contact between the sample and the tool by avoiding completely the effect of mechanical vibrations. The main disadvantages of these processes are the low-speed machining and the detrimental effects of the high temperature gradients that involve significant changes in the near surface layers [1]. The nature and the extent of these changes depend on the specific process parameters, on the microstructural and thermophysical characteristics of the machined material and on the properties of the electrode tool (in case of EDM) [2]. Numerical studies of thermal aspects of the EDM have been developed for different types of thermal loading and different types of machined materials. Shuvra et al. [4] and Ghanem et al. [5] used a heat source disc with a constant radius whereas Schuse et al. [6] and Yadav et al. [7] adopted a heat source Gaussian distribution. All these studies confirm that:

- Under the conditions of EDM, metal is removed by successive electrical sparks that arise between the electrode tool and the immersed sample in the dielectric liquid. 
- Each produced spark acts as a heat source and causes an increase in local temperature $\left(>3,000^{\circ} \mathrm{C}\right)$ for a very short time (from 2 to $100 \mu \mathrm{s}$ ).

Therefore, material that is heated above the melting temperature is removed and flushed away by the dielectric fluid. In addition, the microstructural and mechanical properties of the remaining layers will undergo changes as reported in the literature $[1,2,5,6,8-10]$. Numerous studies have been devoted to the identification of metallurgical transformations on the surface and subsurface layers of different materials machined by this process:

- In the case of hardenable steels, EDM leads to a structure of three layers, a white one, a quenched martensite and a transition layer $[5,8,9]$.

- In the case of non-hardenable steels, metallurgical transformations result only in the formation of a recast layer with a dendritic structure $[5,10]$.

These changes create significant reduction in the endurance limit of EDM components with respect to other machining process [8, 9, 11-17]. Ghanem et al. reported a reduction by $35 \%$ in the endurance limit of EDM machined X160CrMoV12 steel components compared to parts obtained by milling process $[8,9]$. Grosh [13] has indicated that EDM reduces the endurance limit of the EN X210Cr12A tool steel by $50 \%$ of its value evaluated when turning is used. Tadao and Takeo $[14,15]$ have shown that EDM lowers by $60 \%$ the endurance limit of the cemented carbide D20 comparatively to polishing process. When EDM was used instead of laser cutting, Kisuke and Katsuji [16] have noticed a reduction by $13 \%$ of the endurance limit of carbon steel $(0.45 \% \mathrm{C})$. Hocheng et al. [18] reported an improvement in the wear resistance of EDM machined $\mathrm{SiC} / \mathrm{A}$ parts, compared to grinding.

The EDM surface corrosion resistance has encountered little interest [19-23] despite of its importance for many applications of metallic components manufactured by this process and used in more or less aggressive environments typically in aerospace, nuclear power plant and biomedical dental implant industries [1-3, 24-28]. Furthermore, the available data on the corrosion resistance of finished surface by EDM is incomplete and sometimes controversial to provide any meaningful conclusion. Indeed, Yan et al. [20] show that surfaces of an $\mathrm{Al}-\mathrm{Zn}-\mathrm{Mg}$ aluminium alloy machined by EDM have greater corrosion resistance, evaluated by weight loss in a $10 \%$ solution of $\mathrm{NaOH}$, compared to surfaces finished by grinding. The authors attribute this enhancement to the role of the amorphous layer formed by EDM in improving the resistance to uniform corrosion of these alloys. They also show that corrosion resistance is significantly improved when defects such as micropores, cracks and discharge craters in the white layer are removed by a special EDM electrode and burnishing by $\mathrm{ZrO}_{2}$ balls. However, Uno et al. [21] show that surfaces of low-alloyed steel C (0.15\%), Ni (3\%), Al (1\%) and $\mathrm{Cu}(1 \%)$, machined by electron beam with large irradiated area have greater resistance to corrosion than surfaces obtained by EDM or by grinding. Authors explain this result by the absence of the white layer and low surface roughness obtained by an electron beam at optimised operating conditions. Based on this result, Tsai et al. [22] developed a sintered electrode tools made in $\mathrm{Cu}-\mathrm{Cr} 80-20 \%$ composite to improve the uniform corrosion resistance of the AISI 1045 EDM surfaces. The authors show an improvement of steel corrosion resistance by reducing the thickness of the white layer and the crack density and by favouring the migration of chromium from the electrode tool to the surface of the work piece. However, Ntasi et al. [23] demonstrated that EDM machining compromise the corrosion resistance of $\mathrm{Cr}-\mathrm{Co}$ alloys and grade II CpTi implant dental materials. The authors attributed the inferior corrosion resistance of EDM surface, compared to the conventional machining surface, to the role of different elemental composition and surface texture in the occurrence of galvanic phenomenon and an increase of surface vulnerability to pitting and crevice corrosion. Obara et al. [19] have identified specific phenomena of corrosion in the case of the electrical discharge machining of WC-Co composite, by selective dissolution of cobalt in water used as a dielectric fluid.

Kathuria et al. [28] reveal, on the basis of accumulation of wear debris around the implant, the existence of real risks of emission of toxic elements in the human body in the form of $\mathrm{Cr}^{6+}, \mathrm{Mo}^{6+}, \mathrm{Fe}^{3+}, \mathrm{Co}^{2+}$ and $\mathrm{Ni}^{2+}$ ions, by corrosion in vitro physiological fluid of AISI316L SS used for fabrication of expansion cardiovascular stents by micro EDM or by laser beam. This suggests the need of understanding and assessment of the white layer role on the localised corrosion resistance of AISI316L SS, proposed by this study. The approach used consists to compare the corrosion resistance of surfaces generated by EDM, under different machining conditions, to diamond polished ones. The results will be discussed on the basis of microgeometrical, microstructural and mechanical properties of surface layers. Scanning electron microscopy (SEM) observation, energy dispersive microanalysis (EDX) analysis and Xray diffraction will be used to investigate microstructure and phase composition of white layer. The resistance to pitting corrosion initiation and propagation, intergranular corrosion (IGC), and residual stress corrosion cracking (RSCC), will be evaluated by an electrochemical tests coupled with SEM examination of surface before and after corrosion testing.

\section{Material and machining conditions}

This study focuses on the AISI316L SS austenitic stainless steel that is known for its good localised corrosion resistance. This material has been selected to produce some biomedical components by EDM machining that could be 
Table 1 Chemical composition of AISI316L SS

Contents (wt $\%$ )

\begin{tabular}{lllllllll}
\hline $\mathrm{C}$ & $\mathrm{Si}$ & $\mathrm{Mn}$ & $\mathrm{P}$ & $\mathrm{S}$ & $\mathrm{Cr}$ & $\mathrm{Ni}$ & $\mathrm{Mo}$ & $\mathrm{Fe}$ \\
\hline 0.017 & 0.56 & 1.21 & 0.025 & 0.001 & 17.6 & 11.1 & 2.16 & Balance \\
\hline
\end{tabular}

sensitive to corrosion in vitro physiological fluid. The chemical composition of this material is reported in Table 1. The as-received microstructural, mechanical and thermal characteristics are reported in Table 2.

EDM machining is performed on a Languepin SE1000 machine, equipped with parameter control system that includes voltage, discharge current, duration and frequency of discharge and dielectric flow. The electrode tool is made in graphite. It has a cylindrical shape containing a hole that is used to inject the dielectric liquid in the inter-electrode gap at a constant flow. The dielectric fluid used was paraffin oil.

The machining operating conditions used in this study are reported in Table 3. These parameters are selected to explore the machining conditions for high and low material removal rates depending on the discharge current $\left(i_{e}\right)$. The average gap voltage $\left(\hat{u}_{e}\right)$ is $46 \mathrm{~V}$. The machining conditions going from roughening $\left(i_{e}=50 \mathrm{~A}\right)$ to finishing $\left(i_{e}=2 \mathrm{~A}\right)$ have been chosen in order to produce a large range of sublayer thickness and properties. The reference specimen was conventionally finished by diamond polishing.

\section{Testing}

\subsection{Identification techniques of surface changes}

Surface changes resulting from the material-process interactions under EDM conditions were identified by appropriate experimental techniques:

- Roughness measurement for microgeometrical changes.

- SEM coupled with EDX analyses for chemical and microstructural changes and thermal crack network characterization.

- Vickers microhardness measurements were made to characterise the effect of microstructure and chemical changes on the near surface layer properties.

- X-ray diffraction data for EDM induced phase identification were collected with a Siemens D5000 equipped with Co-Ka radiation, $0.178919 \mathrm{~nm}$, at $35 \mathrm{KV}$ and $30 \mathrm{~mA}$. The $2 \theta$ scanned range was $35-130^{\circ}$, with a step of $0.05^{\circ}$ and $10 \mathrm{~s} / \mathrm{step}$. For structural refinements, the FULLPROF. $2 \mathrm{k}$ was used as Rietveld software. The background was approximated by a linear interpolation of 39 data points. The peak profile retained for the refinement study was a Thompson-Cox-Hastings pseudo-Voigt.

- X-ray diffraction technique for residual stress measurements using a SET-X diffractometer equipped with a PSD detector, a high voltage power supply and a classical PSI goniometer. The measurement conditions are reported in Table 4.

\subsection{Corrosion tests}

The corrosion resistance of the machined surfaces is evaluated by electrochemical tests completed by metallographic examinations under SEM of morphological and elemental alteration before and after corrosion testing:

- Pitting corrosion was evaluated by potentio-dynamic cyclic and potentio-kinetic tests performed in synthetic sea water as recommended by ASTM1141-86, using a Voltalab 32 potentiostat. The tests are performed with a potential scanning rate of $2.5 \mathrm{mV} / \mathrm{s}$ in the potential scanning range $-300,600 \mathrm{mV} / \mathrm{SCE}$.

- Intergranular corrosion was evaluated by double loop electrochemical potentiokinetic reactivation on the basis of the density of reactivation current $\left(I_{r}\right)$ /density of activation current $\left(I_{a}\right)>1 \%$ criterion (Fig. 1$)$. The operating conditions of the tests are reported in Table 5 as recommended in previous work [29].

- RSCC susceptibility was evaluated by SEM observation of the sample surface before and after immersion during $48 \mathrm{~h}$ in a $40 \%$ magnesium chloride solution $\left(\mathrm{MgCl}_{2}\right)$ heated at $140^{\circ} \mathrm{C}$.

\section{Results}

\subsection{EDM surface characterization}

The EDM thermal cycles lead to substantial surface changes. The nature and extent of these changes depend

Table 2 Microstructure, mechanical and thermal properties of AISI316L SS

\begin{tabular}{|c|c|c|c|c|}
\hline \multirow[t]{2}{*}{ Metallurgical structure } & \multirow{2}{*}{$\begin{array}{l}\text { Thermal conductivity } \lambda \\
\left(\mathrm{W} \mathrm{m}{ }^{-1}{ }^{\circ} \mathrm{K}^{-1} \text { ) at } 25^{\circ} \mathrm{C}\right.\end{array}$} & \multicolumn{3}{|l|}{ Mechanical properties } \\
\hline & & Ultimate tensile stress UTS (MPa) & Elongation A (\%) & Hardness (Hv) \\
\hline Austenite & 16 & 620 & 35 & 230 \\
\hline
\end{tabular}


Table 3 EDM conditions

\begin{tabular}{lll}
\hline Machining conditions & Finish & Rough \\
\hline Discharge current, $i_{e}(\mathrm{~A})$ & $2-5-12$ & $20-25-30-50$ \\
Discharge duration, $t_{e}(\mu \mathrm{s})$ & 5 & \\
Pulse interval time, $t_{o}(\mu \mathrm{s})$ & 2 & \\
Duty factor $(\tau)(\%)$ & 80 & \\
Average gap voltage, $\hat{u}_{e}(\mathrm{~V})$ & 120 \\
Open-gap voltage, $\mathrm{u}_{\mathrm{i}}(\mathrm{V})$ & Positive \\
Polarity & Graphite $($ Ellor7, intermediate \\
Tool for machining & size of grains $\approx 35 \mu \mathrm{m})$ \\
& 20 \\
Diameter of the tool electrode $(\mathrm{mm})$ & Paraffin oil $($ dynamic \\
Dielectric liquid & viscosity) $\mu=2.4 \times 10^{-3}$ Pa.s \\
Flow of dielectric injection in & 2 \\
inter-electrode space (liter per hour) & \\
\hline
\end{tabular}

on the machining conditions and particularly on the electric energy converted into heat on the sample surface. Such changes cover microgeometrical, surface integrity, microstructural, chemical and mechanical aspects.

\subsubsection{Microgeometrical surface changes}

The EDM surface shows rough and porous texture with characteristic melting drops with craters assigned to the collapse of plasma columns during machining. Craters are as deeper as the material volume affected by the heat flow increases (Fig. 2). This volume is directly proportional to the discharge current. The total roughness $\left(R_{t}\right)$ increases from 30 to $320 \mu \mathrm{m}$ while the discharge current varies from finishing $(2 \mathrm{~A})$ to roughening (50 A) machining conditions (Fig. 3).

Table 4 X-ray diffraction conditions

\begin{tabular}{ll}
\hline Target & $\mathrm{Mn}$ \\
Filter & $\mathrm{Cr}$ \\
Current & $5 \mathrm{~mA}$ \\
Voltage & $20 \mathrm{KV}$ \\
Type of goniometer & Psi \\
Young modulus (E) & $196,000 \mathrm{MPa}$ \\
Poisson ratio (v) & 0.29 \\
Wavelength & $2.102 \AA$ \\
Plane hkl & $311 \gamma$ \\
Bragg Angle & $152.3^{\circ}$ \\
Beam section & $\varnothing=2 \mathrm{~mm}$ \\
Number of Psi angles & 17 \\
Number of Phi angles & $2\left(0^{\circ}\right.$ and $\left.90^{\circ}\right)$ \\
\hline
\end{tabular}

\subsubsection{Surface integrity}

SEM investigations of EDM surfaces reveal the presence of defects such as micropores, deposition of resolidified material and thermal cracks as a consequence of the rapid heating and cooling processes (Fig. 4). The crack distribution seems to be a thermal fatigue damage generated by repeated electric sparks. These electric charge-discharge sequences lead to high amplitude of thermal stresses at the outer layers of the machined material (less than $100 \mu \mathrm{m}$ ), while the bulk of the material is still cold.

The density of thermal cracks increases with discharge current increasing. It varies from 5 to $25 \mu \mathrm{m} / \mu \mathrm{m}^{2}$ when the discharge current increases from 2 to $50 \mathrm{~A}$. These cracks are called "short" because they do not penetrate deeply in the a

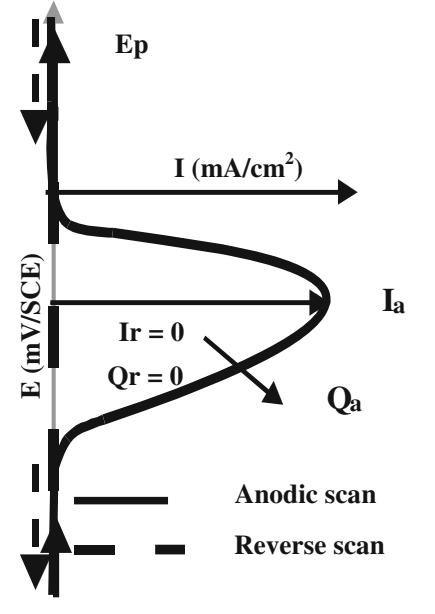

b

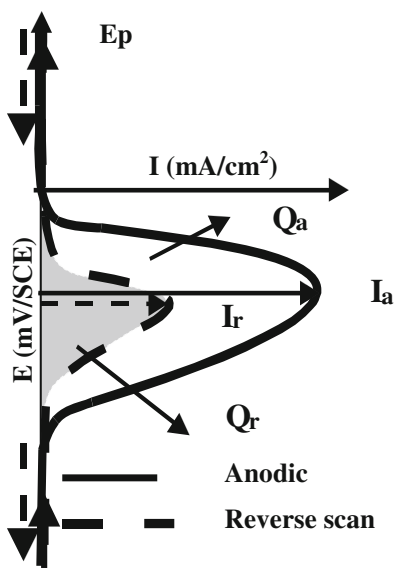

Fig. 1 Principle of DL-EPR technique and IGC sensitization criterion; a solution annealed state and $\mathbf{b}$ sensitised state 
Table 5 Operating conditions of DL-EPR test [29]

\begin{tabular}{llll}
\hline Medium & $\begin{array}{l}\text { Temperature } \\
\left({ }^{\circ} \mathrm{C}\right)\end{array}$ & $\begin{array}{l}\text { Potential scanning } \\
\text { rate }(\mathrm{mV} / \mathrm{s})\end{array}$ & $\begin{array}{l}\text { Potential scanning } \\
\text { range }(\mathrm{mV} / \mathrm{ECS})\end{array}$ \\
\hline $\mathrm{H}_{2} \mathrm{SO}_{4} 0.5 \mathrm{M}+\mathrm{NH}_{4} \mathrm{SCN} 0.01 \mathrm{M}$ & 25 & 1 & $-300 \leftrightarrow 400$ \\
\hline
\end{tabular}

material: they vary from 5 to $40 \mu \mathrm{m}$ when the discharge current increases from $2 \mathrm{~A}$ (finishing EDM) to $50 \mathrm{~A}$ (roughening EDM).

\subsubsection{Microstructural changes}

Optical microscope cross-section examination of EDM machined specimens shows three different layers (Fig. 5):

(a) White layer corresponding to the melted area with depth irregularities (Fig. 5). The thickness of the white layer varies from 5 to $80 \mu \mathrm{m}$ when the discharge current increases from 2 to 50 A (Fig. 6). This layer is composed by a series of sublayers marked by solidification fronts during the cooling of the melted material resulting from repeated discharge sparks (Fig. 5).

White layer cross-section backscattering electron image highlights two sublayers with high mean atomic number (white) and low atomic number (black; Fig. 7a):

- Outer layer (white sublayer) with fully dendritic structure likely supposed the recast material formed from unflushed and redeposited EDM removed material (Fig. 7b).

- Inner layer (dark sublayer) with structure characterised by columnar at the interface white layer/bulk material followed by dendrites oriented along the cooling gradient (Fig. 7c).

White layer phases were identified by X-ray diffraction. The X-ray beam penetration depth (an average of $6 \mu \mathrm{m}$ ), allows to irradiate mainly the white layer materials and therefore the identification concerns phases of this zone. Figure 8 revealed three different phases: carbon-enriched austenite $(\gamma), \mathrm{M}_{7} \mathrm{C}_{3}$, and $\varepsilon$-carbides $\left(\mathrm{M}_{3} \mathrm{C}\right.$; where $\left.M=\mathrm{Fe}, \mathrm{Cr}\right)$. Rietveld lattice parameters of these phases are reported in Table 6.

(b) Heat-affected layer located beneath the white layer, with depth and austenitic grain size irregularities. It corresponds to significantly heated material but not melted during EDM process. The larger grain size results from dynamic recrystallisation at high temperature (Fig. 5).

(c) Bulk material associated to the core material thermally unaffected austenitic structure (Fig. 5).

The microhardness measurements reveal a high near surface hardness (700-800 Hv), corresponding to the white layer followed by an abrupt drop to bulk material hardness (200 Hv). The level and the depth of EDM hardening increase with the discharge current increasing (Fig. 9). The high near-surface hardening $(\sim 800 \mathrm{HV})$ is likely assumed to the metallic carbide dispersion in the white layer.

\subsubsection{Chemical changes}

EDX analysis confirms that the carbon content varies within the white layer, ranging from 3 to $9 \mathrm{wt} \%$ at the surface of the workpiece down to $0.017 \mathrm{wt} \%$ (formally $0 \%$ considering the accuracy) which is the reference carbon content of the steel. This result is confirmed by EDX measurements realised at the same conditions that conventionally polished surface (Fig. 10).

This suggests that chromium and iron carbides dominate the surface white layer. Then, analysed carbon corresponds to its allied form as suggested in other alloys subjected to EDM machining [10].
Fig. 2 EDM surface texture; a roughening conditions $\left(i_{e}=50 \mathrm{~A}\right)$ and $\mathbf{b}$ finishing conditions $\left(i_{e}=2 \mathrm{~A}\right)$
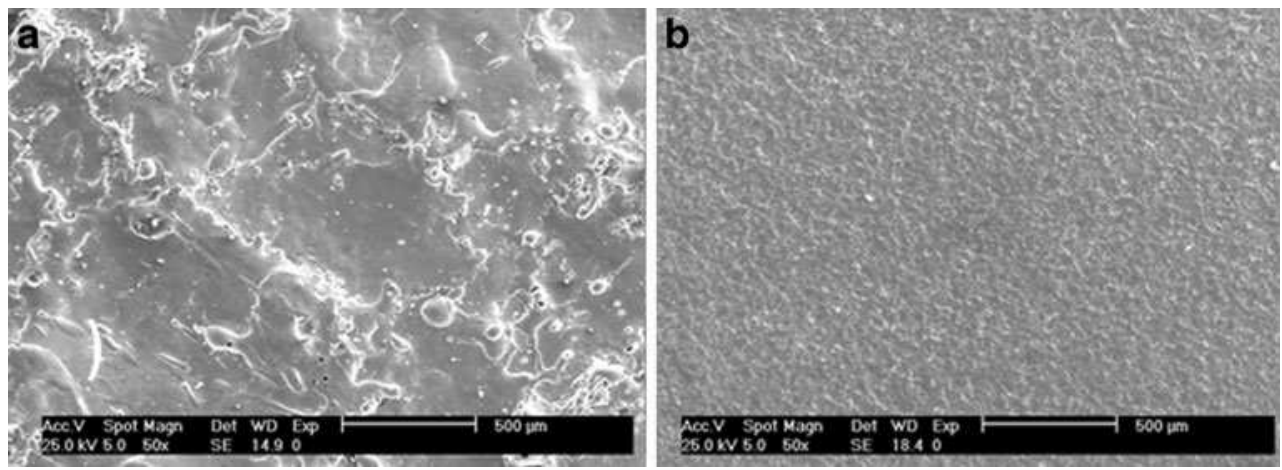


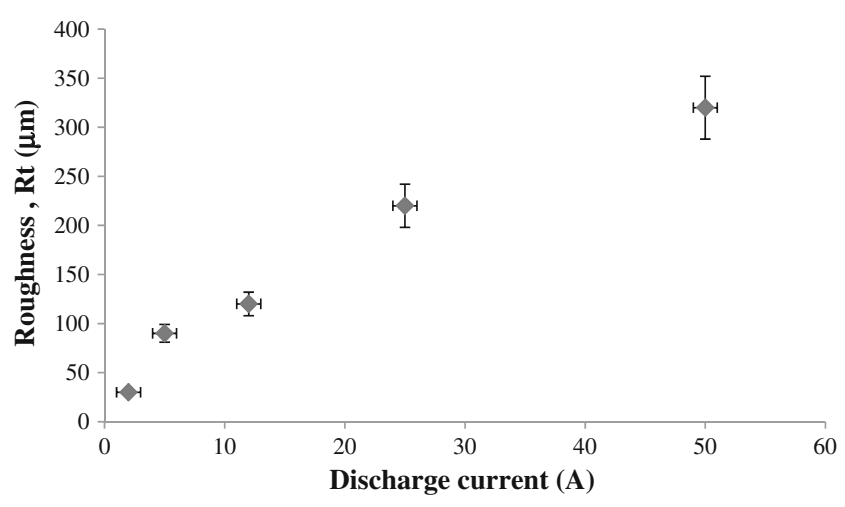

Fig. 3 Effect of EDM conditions on the surface roughness

Back scattering electron image of EDM surface illustrates randomly distributed areas of low mean atomic number (black, zone 1) and high atomic number (white, zone 2). The corresponding quantitative analysis shows that the black areas are rich in chromium (about $25 \mathrm{wt} \%$ ) while the white layer chromium content is around $15 \mathrm{wt} \%$ (Fig. 11). Moreover, X-ray mapping shows that the interdendritic space of redeposited material is $\mathrm{Cr}$ - and Mo-depleted zones comparatively to the dendritic axis and arms (Fig. 12).

\subsubsection{Mechanical changes}

In the EDM-affected layers, a plane isotropic distribution of residual stresses is created with a high gradient at the in depth profile. The maximum values, obtained in sub-layers, increase with increasing the discharge current. The white layer residual stresses are partly released on the near surface (Fig. 13). Such stresses are the consequence of the microstructural changes

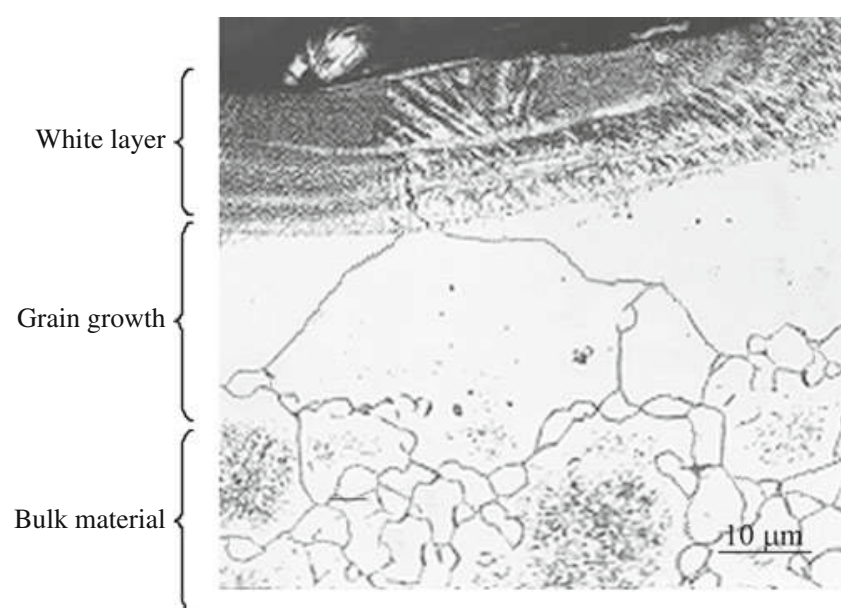

Fig. 5 White and heat-affected layers induced by EDM

and contraction during intense cooling of the surface layers, markedly expanded by the heat load, generated by the EDM process.

\subsection{Evaluation of white layer corrosion resistance}

The results of cyclic potentiodynamic and potentiostatic tests show that EDM significantly alters the pitting and crevice corrosion resistance of AISI316L SS surfaces in chloride medium (Fig. 14). Moreover, the appearance of $I_{r}$ during the double-loop electrochemical potentiokinetic reactivation (DL-EPR) tests, performed under appropriate operating conditions [29], is indicative of an IGC sensitivity induced by EDM (Fig. 15). The results of electrochemical tests and micrographic examinations performed on the samples to evaluate the resistance of
Fig. 4 EDM surface cracks and defects

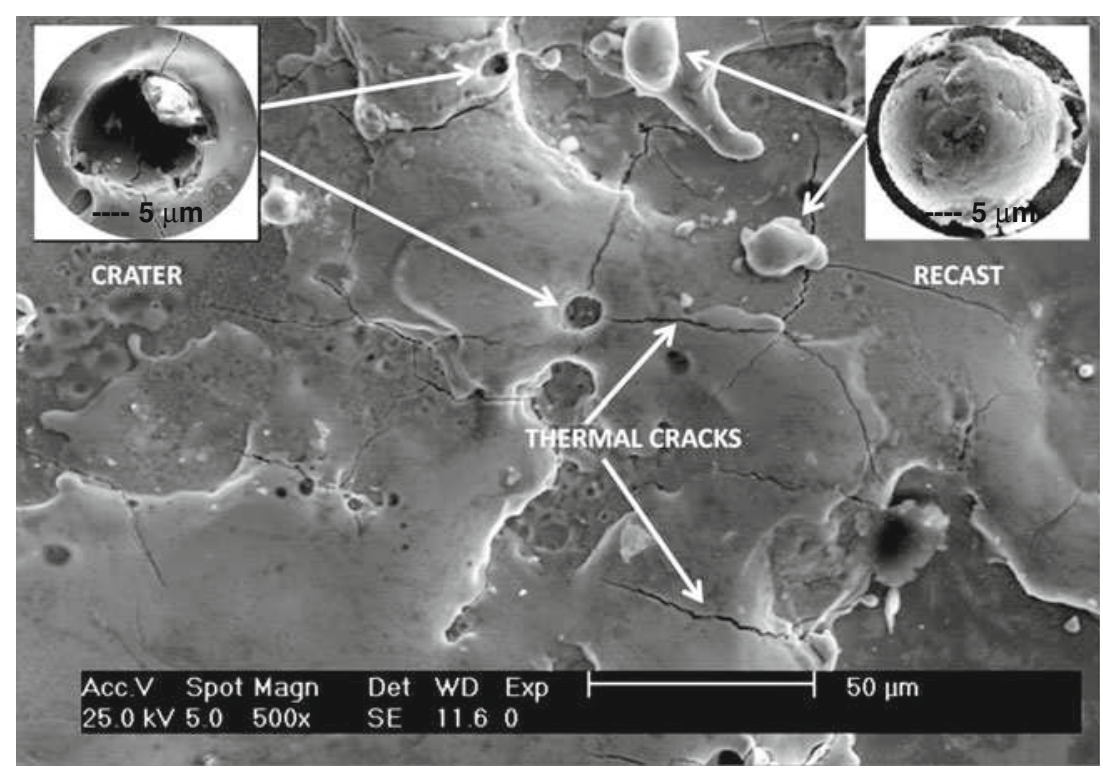




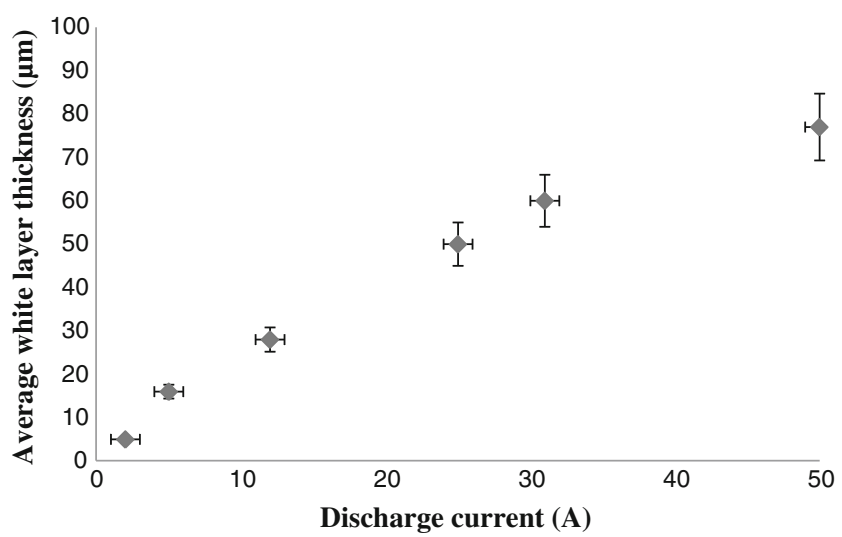

Fig. 6 Effect of EDM discharge current on the average white layer thickness

EDM surfaces to various forms of localised corrosion are compared to those of conventionally polished surface. The corrosion testing data are reported in Table 7 which shows the following comments:

\subsubsection{Resistance to pitting initiation and the crevice propagation}

The values of pitting critical temperature (PCT, $16-32^{\circ} \mathrm{C}$ ), pitting potential (Ep, 12-230 $\mathrm{mV} / \mathrm{SCE})$, and repassivation potential (Er, -300 to $-50 \mathrm{mV} / \mathrm{SCE}$ ), reported in Table 7 (column D) are lower for EDM surfaces compared to those

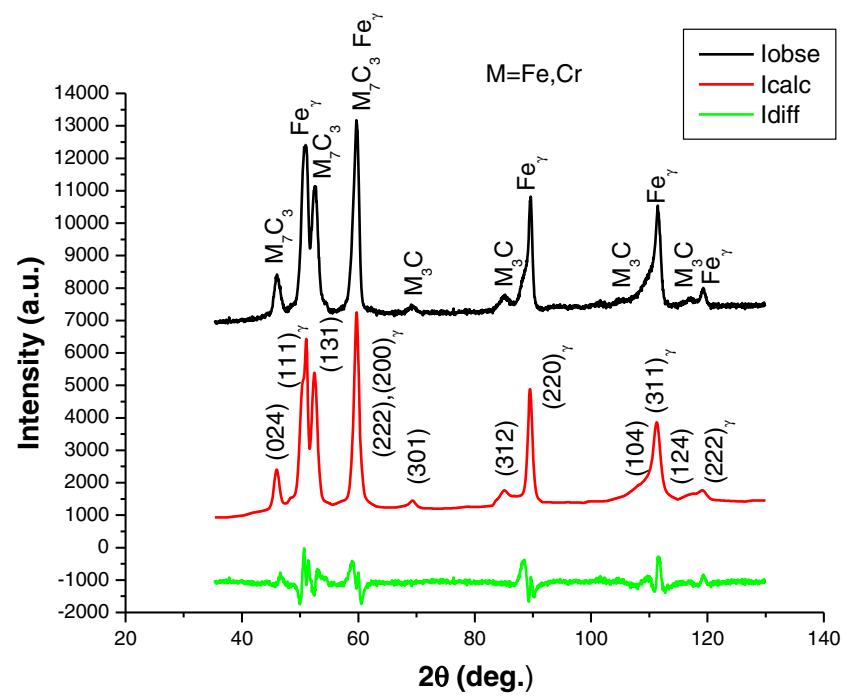

Fig. 8 X-ray spectrum of the white layer, where $I_{\text {obse }}$ and $I_{\text {calc }}$ are the observed and calculated intensity respectively and $I_{\text {diff }}$ is the difference spectra

of the conventionally finished surface $\left(\mathrm{PCT}=38^{\circ} \mathrm{C}\right.$; Ep, $450 \mathrm{mV} / \mathrm{SCE}$ and $\mathrm{Er}=-68 \mathrm{mV} / \mathrm{SCE}$ ). This reflects that EDM deteriorates significantly the pitting corrosion resistance. Similarly, much higher $\mathrm{pH}$ activation values of EDM surface show a lower resistance to the pitting propagation. This weakening is more and more important with an increase of current discharge intensity.
Fig. 7 White layer structure; a recast and melted sublayers, $\mathbf{b}$ dendritic structure of recast material and $\mathbf{c}$ dendritic and columnar structures of melted material

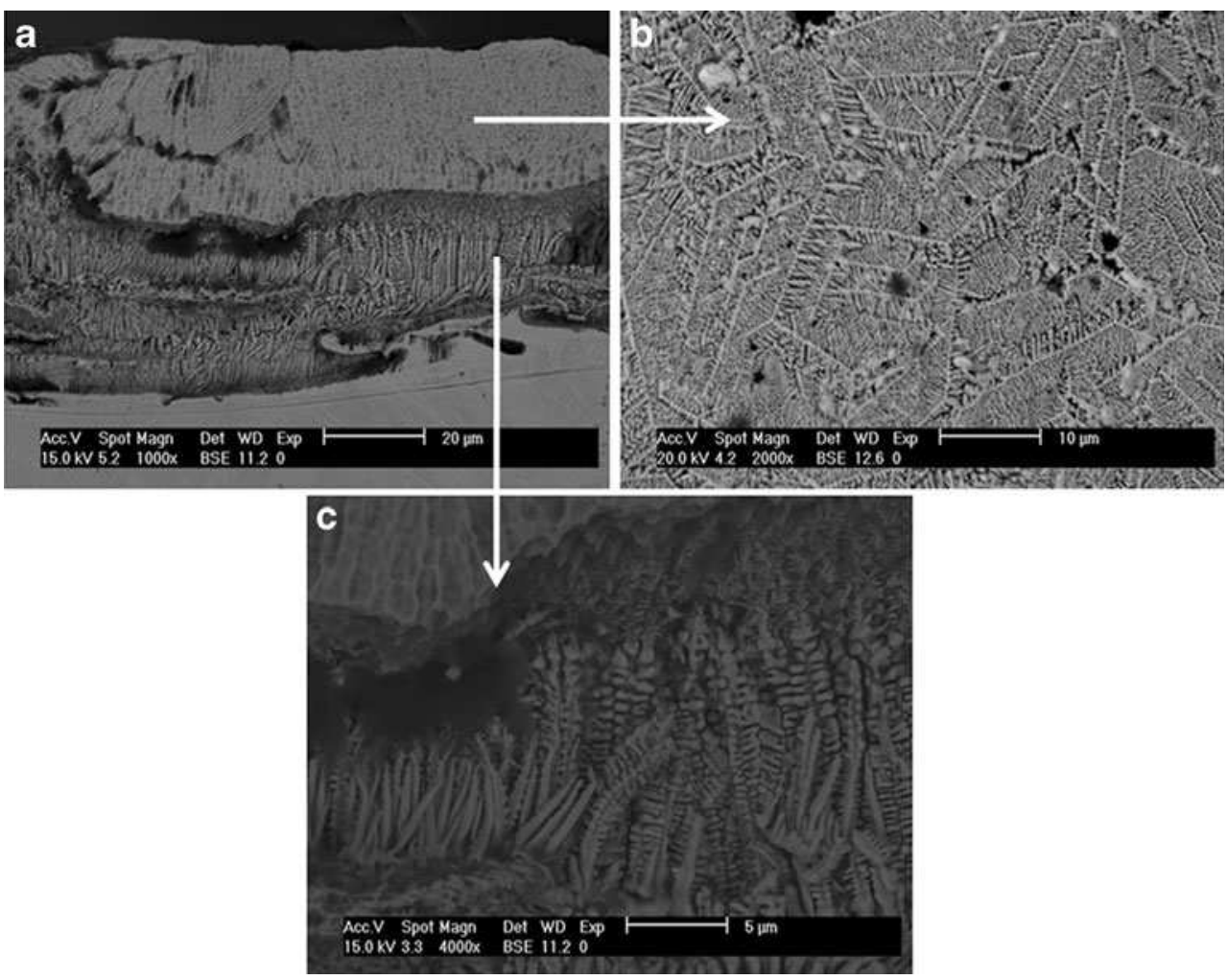


Table 6 Lattice parameters of white layer phases calculated by Rietveld refinement method

\begin{tabular}{|c|c|c|c|}
\hline Phase & Space group & Lattice parameters & Rietveld goodness of fit factors \\
\hline$\gamma$ & $\mathrm{F} \mathrm{m}-3 \mathrm{~m}$ & $\begin{array}{l}\text { Cubic } \\
\begin{array}{l}a=0.35932 \pm 0.00001 \mathrm{~nm} \\
\alpha=\beta=\gamma=90\end{array}\end{array}$ & $\begin{array}{l}\text { Bragg } R \text { factor, } 5.88 \\
\text { RF factor, } 2.90\end{array}$ \\
\hline $\mathrm{M}_{3} \mathrm{C}, M=\mathrm{Fe}, \mathrm{Cr}$ & $\mathrm{Pn} \mathrm{m} \mathrm{a}$ & $\begin{array}{l}\text { Orthorhombic } \\
a=0.50414 \pm 0.00031 \mathrm{~nm} \\
b=0.76662 \pm 0.01018 \mathrm{~nm} \\
c=0.44757 \pm 0.00017 \mathrm{~nm} \\
\alpha=\beta=\gamma=90\end{array}$ & $\begin{array}{l}\text { Bragg } R \text { factor, } 8.45 \\
\text { RF factor, } 5.70\end{array}$ \\
\hline $\mathrm{M}_{7} \mathrm{C}_{3}, M=\mathrm{Fe}, \mathrm{Cr}$ & $\mathrm{Pn} \mathrm{ma}$ & $\begin{array}{l}\text { Orthorhombic } \\
a=0.44801 \pm 0.00004 \mathrm{~nm} \\
b=0.69279 \pm 0.00007 \mathrm{~nm} \\
c=1.22170 \pm 0.00043 \mathrm{~nm} \\
\alpha=\beta=\gamma=90\end{array}$ & $\begin{array}{l}\text { Bragg } R \text { factor, } 2.66 \\
\text { RF factor, } 1.52\end{array}$ \\
\hline
\end{tabular}

\subsubsection{IGC sensitivity}

The values of the $I_{r} / I_{a}$ ratio varies from EDM finishing conditions $\left(I_{r} / I_{a}=28 \%\right)$ to EDM roughening conditions $\left(I_{r} / I_{a}=60 \%\right)$. This confirms a clear sensitivity to IGC of EDM surfaces in comparison to the conventionally machined surface $\left(I_{r} / I_{a}=0 \%\right)$. SEM metallographic examinations of the EDM surface before and after DL-EPR testing reveal selective dissolution in the inter-dendritic areas of resolidified structure of the white layer (Fig. 16).

\subsubsection{Susceptibility to RSCC}

SEM observations of specimens, immersed during $48 \mathrm{~h}$ in a $40 \% \mathrm{MgCl}_{2}$ heated at $140^{\circ} \mathrm{C}$, show secondary microcrack network that are very shallow and clearly separated from the primary EDM thermal cracks (Fig.17). This phenomenon is observed for roughening and finishing EDM conditions $\left(i_{e}=\right.$ 2-50 A) and reveals the high susceptibility to RSCC of

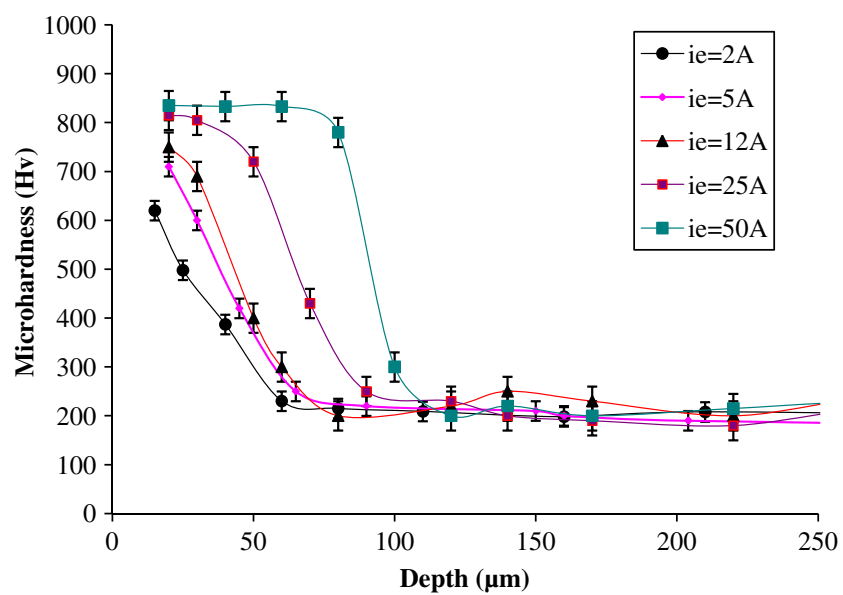

Fig. 9 White layer hardness profiles white layer. This suggests that the threshold cracking stress in this environment is well below $200 \mathrm{MPa}$ (Fig. 13).

a

Elem Wt $\%$ At $\%$

CK $\quad 0.00 \quad 0.00$

SiK $\quad 0.65 \quad 1.28$

MoL $2.50 \quad 1.45$

CrK 17.5318 .76

FeK 68.1867 .94

NiK 11.1410 .56

Total $\mathbf{1 0 0 . 0 0 1 0 0 . 0 0}$

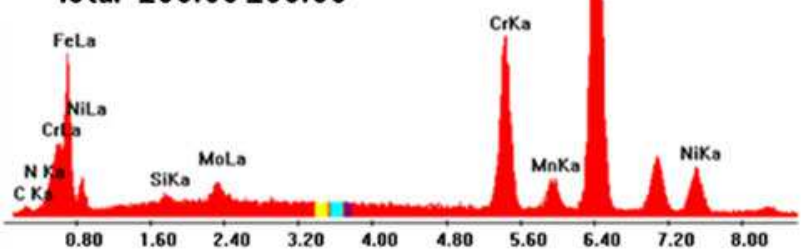

b

Elem Wt $\%$ At $\%$

C K 9.3932 .32

SiK $0.96 \quad 1.41$

MoL $2.14 \quad 0.92$

CrK 16.5513 .16

FeK 60.7044 .96

NiK 10.267 .23

Total $\mathbf{1 0 0 . 0 0 1 0 0 . 0 0}$

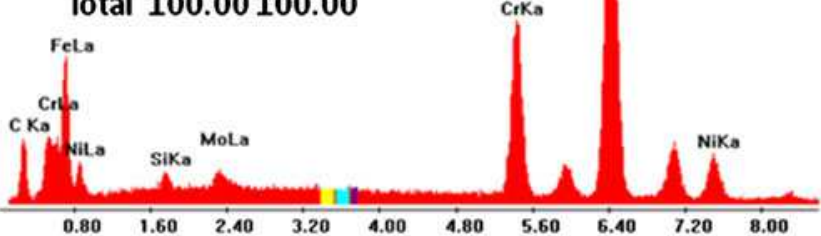

Fig. 10 EDX analysis showing carbon-enriched EDM surface; a bulk material carbon content and $\mathbf{b}$ white layer carbon content 


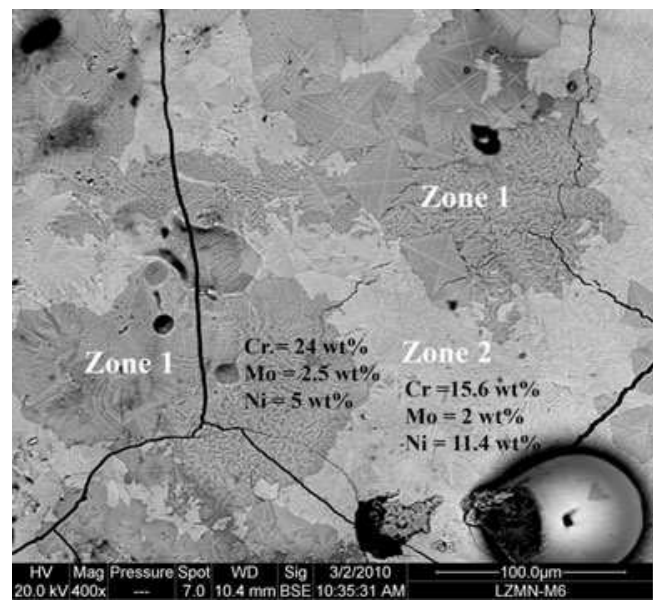

Fig. 11 Structure and chemical composition heterogeneities of EDM surface

\section{Discussion}

The thermal cycles created by the discharge sparks during EDM are characterised by a high heating $\left(\mathrm{Vh} \approx 10^{5}{ }^{\circ} \mathrm{C} / \mathrm{s}\right)$ and cooling rates $\left(\mathrm{Vc} \approx 10^{8}{ }^{\circ} \mathrm{C} / \mathrm{s}\right)$. In addition, the surface layer temperature rises to values ranging from $10^{3}$ to $2.510^{3}{ }^{\circ} \mathrm{C}$ for discharge current intensity as low as $2 \mathrm{~A}$, according to data from the literature [4-7]. These thermal cycles that occur in the presence of a dielectric liquid and electrode

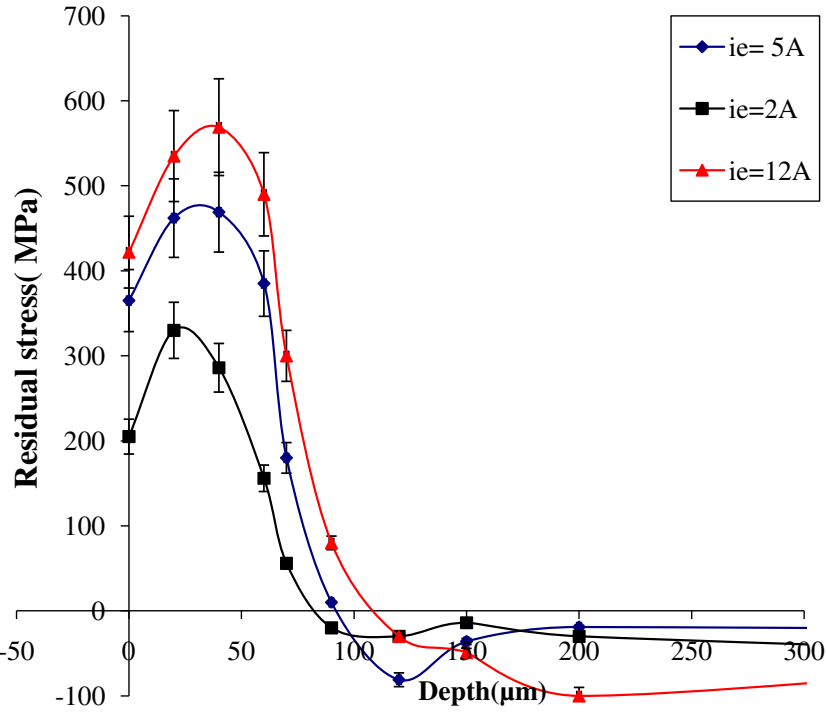

Fig. 13 Tensile residual stress distribution in the EDM affected layers

tool, promote thermal, physical and chemical exchanges. It was previously shown that these exchanges depend on the type of the electrode, workpiece material and the dielectric fluid. The commonly found is that the white layer resulting from solidification of melting zone exhibits high hardness and good adherence to bulk. However, it contains surface irregularities, multiphase materials and microcracks which
Fig. 12 X-ray mapping showing chromium and molybdenum distribution in dendritic structure of recast layer. a Dendritic structure and b X-ray $\mathrm{Cr}-\mathrm{K} \alpha$ (purple) and $\mathrm{Mo}-\mathrm{K} \alpha$ (blue) mapping

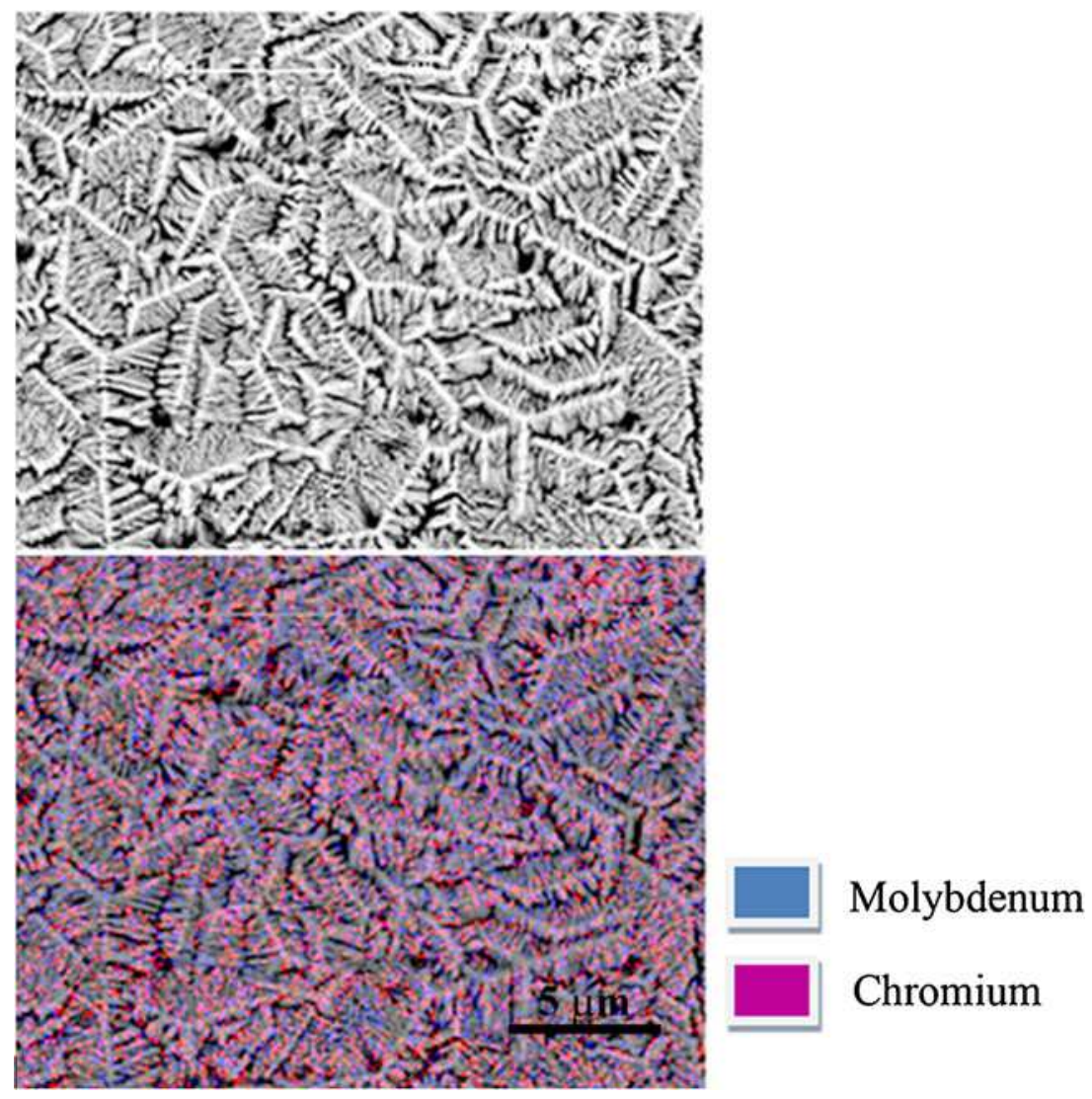



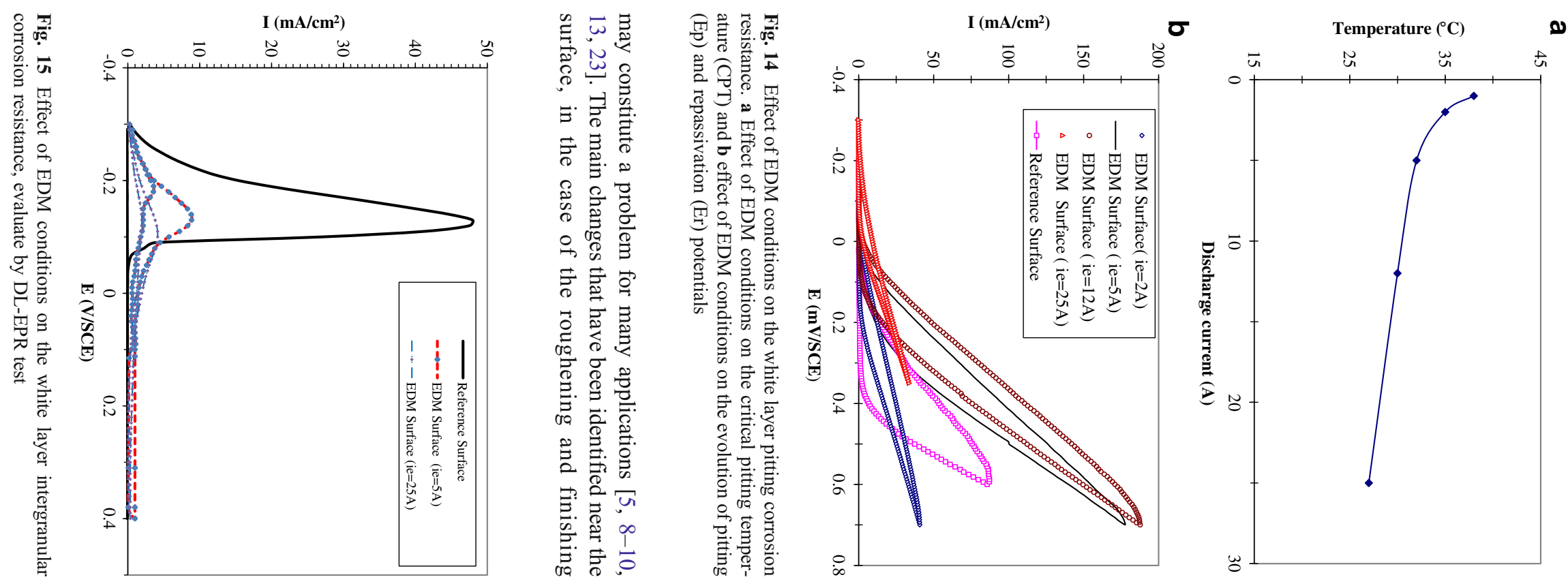

Table 7 Effect of the AISI316L SS white layer properties on the corrosion resistance

\begin{tabular}{|c|c|c|c|c|c|c|c|c|c|c|c|c|c|}
\hline \multirow[t]{4}{*}{ Surface state } & \multirow{4}{*}{$\begin{array}{l}\text { (A) Surface } \\
\text { mode } \\
\text { preparation }\end{array}$} & \multirow{2}{*}{\multicolumn{2}{|c|}{$\begin{array}{l}\text { (B) Micro- } \\
\text { geometrical } \\
\text { change }\end{array}$}} & \multirow{2}{*}{\multicolumn{4}{|c|}{ (C) Surface changes }} & \multicolumn{6}{|c|}{ (D) Localised corrosion resistance } \\
\hline & & & & & & & & \multicolumn{4}{|c|}{ Pitting and crevice resistance } & \multirow{3}{*}{$\begin{array}{l}\text { Intergranular } \\
\text { Sensitization } \\
\text { to IGC } \\
I_{r} / I_{a}(\%)\end{array}$} & \multirow[t]{3}{*}{$\mathrm{RSCC}$} \\
\hline & & & & & & & & \multicolumn{2}{|c|}{ Pitting initiation } & \multicolumn{2}{|c|}{ Pitting propagation } & & \\
\hline & & $R_{a}(\mu \mathrm{m})$ & $R_{t}(\mu \mathrm{m})$ & $\begin{array}{l}\text { Micro-structural } \\
\text { changes }\end{array}$ & Chemical changes & $\begin{array}{l}\text { Mechanical } \\
\text { changes/surface } \\
\text { residual stress (MPa) }\end{array}$ & Surface integrity & $\begin{array}{l}\mathrm{CPT} \\
\left({ }^{\circ} \mathrm{C}\right)\end{array}$ & $\begin{array}{l}\text { Ep } \\
(\mathrm{mV} / \mathrm{ECS})\end{array}$ & $\begin{array}{l}\mathrm{Er} \\
(\mathrm{mV} / \mathrm{ECS})\end{array}$ & $\mathrm{pH}$ & & \\
\hline Reference & $\begin{array}{l}\text { Polished with } \\
\text { diamond paste }\end{array}$ & 0.15 & 1.4 & No & No & -300 & No defects & 38 & 450 & -68 & 1.27 & 0 & $\begin{array}{r}\text { No RSCC } \\
\text { cracking }\end{array}$ \\
\hline \multirow[t]{4}{*}{ EDM } & $\begin{array}{l}i_{e}=2 \mathrm{~A} \\
i_{e}=5 \mathrm{~A}\end{array}$ & $\begin{array}{l}10 \\
11.7\end{array}$ & $\begin{array}{l}30 \\
90\end{array}$ & \multirow{4}{*}{$\begin{array}{l}\text { Dendritic structure } \\
\text { and chromium } \\
\text { carbides } \\
\text { precipitation }\end{array}$} & \multirow{4}{*}{$\begin{array}{l}\text { Carbon enriched } \\
\text { austenite and } \\
\text { interdendritic } \\
\text { chromium depletion }\end{array}$} & $\begin{array}{l}+205 \\
+365\end{array}$ & \multirow{4}{*}{$\begin{array}{l}\text { Thermal cracks, } \\
\text { micro-pores and } \\
\text { material deposits }\end{array}$} & $\begin{array}{l}32 \\
30\end{array}$ & $\begin{array}{l}230 \\
87\end{array}$ & $\begin{array}{l}-50 \\
-292\end{array}$ & $\begin{array}{l}5.35 \\
6.5\end{array}$ & $\begin{array}{l}28.37 \\
32.39\end{array}$ & \multirow[t]{4}{*}{$\begin{array}{l}\text { RSCC } \\
\text { cracking }\end{array}$} \\
\hline & $i_{e}=12 \mathrm{~A}$ & 12.5 & 120 & & & +422 & & 25 & 45 & -133 & $\mathrm{NE}$ & 29.18 & \\
\hline & $i_{e}=25 \mathrm{~A}$ & 19.2 & 220 & & & +460 & & 20 & 18 & -242 & $\mathrm{NE}$ & 46.88 & \\
\hline & $i_{e}=50 \mathrm{~A}$ & 25.7 & 320 & & & +520 & & 16 & 12 & -300 & $\mathrm{NE}$ & 60 & \\
\hline
\end{tabular}

$E p$ pitting potential, $I G C$ intergranular corrosion, $R S C C$ residual stress corrosion cracking, $E r$ repassivation potential, $I_{r}$ density of reactivation current, $I_{a}$ density of activation current, $C P T$ critical pitting temperature, $N E$ non-evaluated 


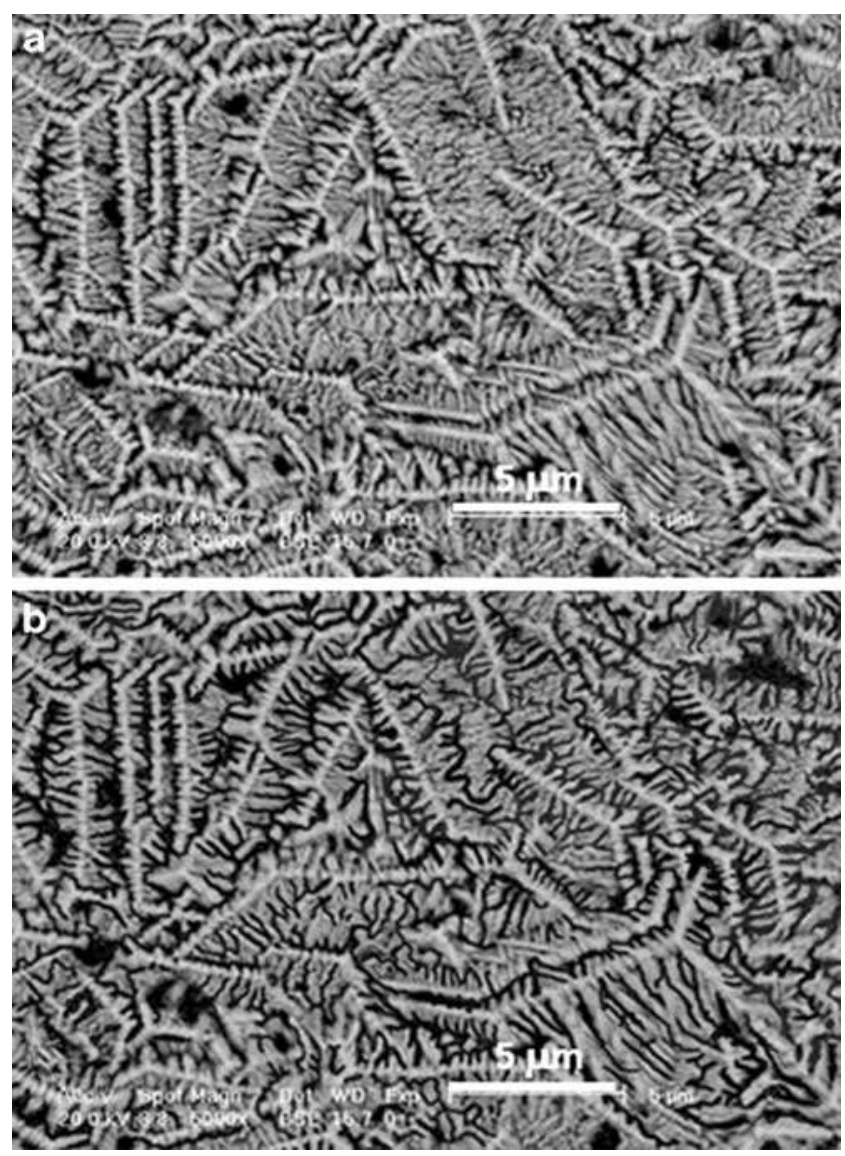

Fig. 16 Selective dissolution of interdendritic spaces after DL-EPR test performed in a solution of $\mathrm{H}_{2} \mathrm{SO}_{4} 0.5 \mathrm{M}+\mathrm{NH}_{4} \mathrm{SCN} 0.01 \mathrm{M}$ at $20^{\circ} \mathrm{C}$ and under $2.5 \mathrm{mV} / \mathrm{s}$ a before DL-EPR test and $\mathbf{b}$ after DL-EPR test interdendritic dissolution

conditions of AISI316L SS with graphite electrode and paraffin oil as dielectric fluid, are summarised in Table 7 (columns B and C). These changes concern the white and heat-affected layers. The depth of the white layer and heataffected layers is lower than $150 \mu \mathrm{m}$. The finishing mode produces a much thinner layer $(5 \mu \mathrm{m})$ in contrast to high energy roughening mode $(80 \mu \mathrm{m})$. The depth of heat affected layer is around $50-150 \mu \mathrm{m}$. The white layer demonstrates changes in surface texture, microstructure, composition and residual stress state that control the corrosion resistance of EDM surface.

\subsection{Surface texture changes}

EDM surface is characterised by pores and craters, which are characteristic of melting drop resulting to a higher roughness texture comparatively to conventional machining process. EDM $R_{t}$ varies from $300 \mu \mathrm{m}$ for roughening conditions to $30 \mu \mathrm{m}$ for finishing conditions, while the turning roughness is usually less than $30 \mu \mathrm{m}$ and the grinding roughness is less than $10 \mu \mathrm{m}$.
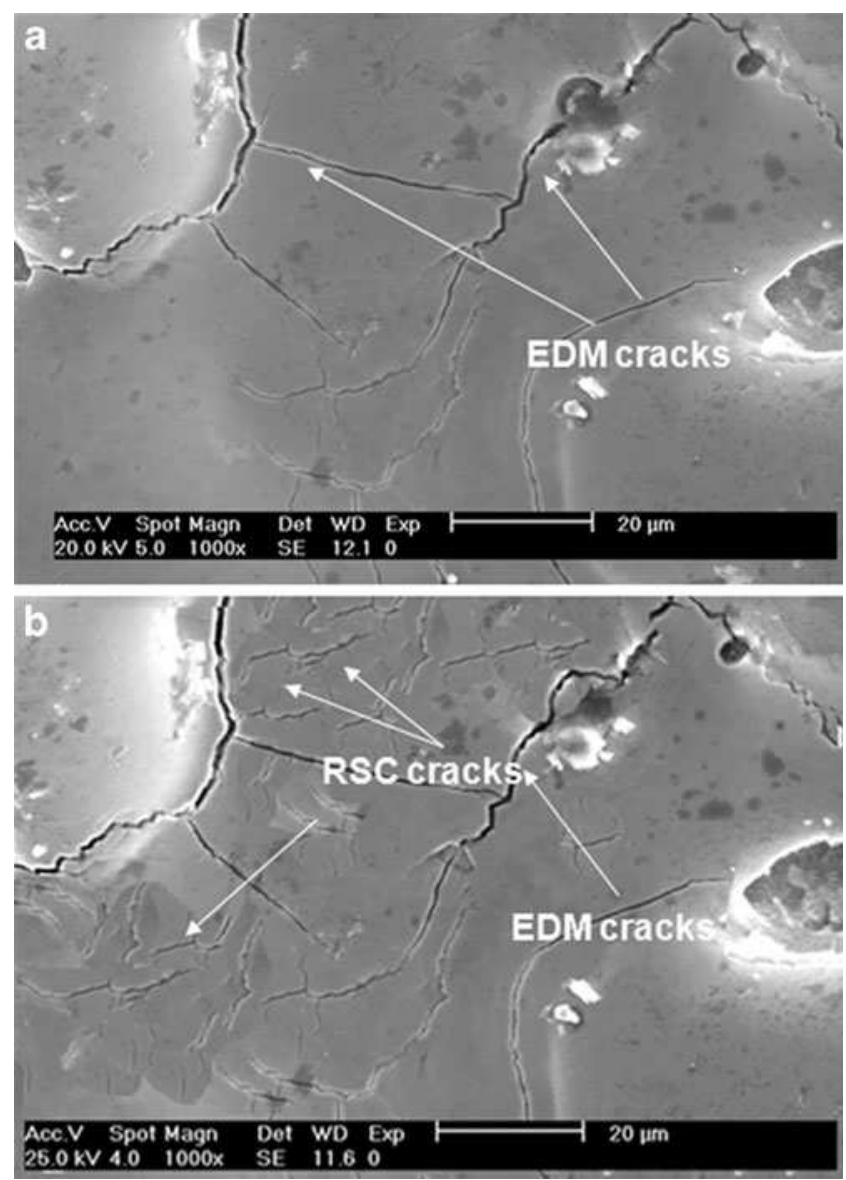

Fig. 17 RSCC of AISI316L SS EDM surface. a Before immersion and b after immersion during $48 \mathrm{~h}$ in $40 \% \mathrm{MgCl}_{2}$ solution heated at $140^{\circ} \mathrm{C}$

\subsection{Microstructure and chemical changes}

The white layer is composed by recast sublayers of some microns in thickness and melted sublayers with dendritic structure. It consists of $\gamma, \mathrm{M}_{3} \mathrm{C}$ and chromium carbides precipitation $\left(\mathrm{Cr}_{7} \mathrm{C}_{3}\right)$. Similar phases have been observed by Cusanelli et al. [10] in the case of EDM ferritic steel. These phases are metastable, they are formed at high temperature with an unknown mechanism. Therefore, a nanostructured morphology can be suspected regarding the high heating and cooling rates required by this process. Carbon is provided from dielectric liquid (paraffin oil) and graphite electrode that diffuse in the melt material leading to the carbide precipitation and not from diffusion of the base material as it has been demonstrated by Cusanelli [10] using a silicon oil as a dielectric fluid. As a consequence, the high carbon content of the white layer revealed by EDX analysis is mainly associated to the distribution of carbides into the recast layer. The high hardness of the white layer is correlated to the chromium and iron carbide dispersion and to the carbon enriched austenite that contributes significantly in its brittleness. 


\subsection{Mechanical changes and corrosion resistance}

The EDM surface residual stress distributions are the consequence of surface layer contractions and induced volume changes resulting from high cooling rate. The carbide volume is larger than austenite one. The volume increase reaches $24 \%$ for $\varepsilon$-carbide and $48 \%$ for $\mathrm{Cr}_{3} \mathrm{C}_{7}$. These changes involve a high tensile stress state in the austenite and that induces the crack nucleation in this phase. The cracks rapidly grow by fast cooling of the brittle white layer and lead to near-surface release of tensile residual stress. All these changes, denoting an extensive electrochemical reactivity action, take place and explain the difference in the localised corrosion behaviour in chloride environments between AISI316L SS surfaces, machined by this process, and reference surfaces polished with diamond paste.

\subsubsection{Resistance to pitting initiation and growth}

The decrease in pitting corrosion resistance of AISI316L SS EDM surface is mainly related to texture irregularities. Indeed, the values of the activation Ep mark significant drops compared to the value of the reference state (450 mV/SCE), for roughening EDM machining conditions $\left(i_{e}>12 \mathrm{~A}\right)$ while finishing conditions $\left(i_{e}<5 \mathrm{~A}\right)$ affect slightly the pitting and crevice corrosion resistance. This weakening of EDM surface corrosion resistance is confirmed by a decrease of corrosion pitting temperature (CPT) and an increase of $\mathrm{pH}$ activation and it is correlated with roughness. The increase of roughness of the resultant surface lead to pitting and crevice corrosion attack. That is why a substantial increase in the pore and crater size has been observed after corrosion testing. Such behaviour might be attributed to a mechanism involving the role of craters, pores and cracks to concentrate very reactive ions $\left(\mathrm{Cl}^{-}\right)$. The galvanic phenomena might also be generated among different phases that constitute the white layer surface by favouring pitting nucleation and growth on the chromium depleted zones. These hypotheses need to be supported by SEM corrosion morphology examination at higher magnification.

\subsubsection{Resistance to IGC}

The white layer is a multiphase material $(\gamma, \varepsilon$-carbides and $\mathrm{Cr}_{7} \mathrm{C}_{3}$ ) with structure and chemical heterogeneities that promote the easily soluble chromium and molybdenum depleted regions. Based on this information, a more detailed explanation can be given for IGC sensitization with the fact that $\mathrm{Cr}_{7} \mathrm{C}_{3}$ is an insoluble phase while interdendritic space dissolves in the corrosion medium. That is why the $I_{r} / I_{a}$ ratio increases comparatively to the surface reference. The chromium depletion is the consequence of the chromium carbide precipitation in the melting structure of the white layer. The chromium level below 13 at.\% is likely reached at the interdendritic space to enhance IGC sensitisation according to Sidhom et al. [29] works on the same austenitic stainless steel. Moreover, the high values of the $I_{r} / I_{a}$ ratio reveal the existence of relatively large areas that are heavily depleted from chromium and molybdenum [29]. The fact that these values $I_{r} / I_{a}$ going from $30 \%$ for finishing conditions to $60 \%$ for roughening conditions, indicates that this phenomenon is mainly related to the existence of the white layer microstructure and chemical heterogeneities at the submicron scale. Indeed, the very fast solidification of the material melted by electric discharge, under non-equilibrium conditions, does not allow the homogenization of chromium contents. Such homogenization is required for the IGC desensitisation of the white layer.

\subsubsection{Resistance to RSCC}

The susceptibility to RSCC of AISI316L SS machined surfaces results from the tensile residual stresses induced by the EDM process. The threshold of cracking stress for the tests performed in this study seems to be reached for all the machining conditions under low or high discharge current, according to data on the same material machined by other processes $[30,31]$. The low depth of the EDM tensile residual stress explains the RSCC short cracks.

\subsubsection{Corrosion resistance improvement of EDM surface}

The improvement of the EDM surface pitting and crevice corrosion needs a control of surface irregularities and microstructure and chemical heterogeneities by finishing machining conditions $\left(i_{e}<5 \mathrm{~A}\right)$. Moreover, an annealing treatment after EDM machining leading to chemical homogenisation and tensile residual stress release prevents the IGC and the RSCC. Indeed, annealing treatment after EDM ensure material self healing, by the elimination of chromium depleted zones (diffusion phenomenon that is thermally activated) and tensile residual stress, simultaneously. Finally, the material removal of white layer by wire brushing restores the corrosion resistance of AISI316L SS.

\section{Conclusion}

It is clear from the results of the present study that EDM machining compromises the corrosion resistance of AISI316L SS. Surface irregularities like pores, craters and the cracks affect substantially the pitting and crevice corrosion resistance. Structure and chemical heterogeneities of the white layer at micron and submicron scales alter the IGC resistance. The chromium-depleted zone resulting from $\mathrm{Cr}_{7} \mathrm{C}_{3}$ at high temperature and during cooling promotes 
the dissolution of interdendritic space material. The tensile residual stresses resulting from rapid cooling and phase changes in the white layer induce cracking of AISI316L SS in chloride medium. Therefore, the white layer generated by the EDM process has to be annealed or completely removed for implants made in AISI316L SS to avoid the formation of toxins.

\section{References}

1. Ho KH, Newman ST (2003) State of the art of electrical discharge machining (EDM). Int J Mach Tools Manuf 43:1287-1300

2. Kumar S, Singh R, Singh TP, Sethi BL (2009) Surface modification by electrical discharge machining: a review. J Mater Process Technol 209:3675-3687

3. Uhlmann E, Piltz S, Doll U (2005) Machining of micro/miniature dies and moulds by electrical discharge machining - recent development. J Mater Process Technol 167:488-493

4. Shuvra D, Mathias K, Klocke F (2003) EDM simulation: finite element-based calculation of deformation, microstructure and residual stresses. J Mater Process Technol 142:434-451

5. Ghanem F, Braham C, Sidhom H (2003) Influence of steel type on electrical discharge machined surface integrity. J Mater Process Technol 142:163-173

6. Schuze HP, Herms R, Juhr H, Schaetzing W, Wollenberg G (2004) Comparison of measured and simulated crater morphology for EDM. J Mater Process Technol 149:316-322

7. Yadav V, Jain V, Prakash Dixit M (2002) Thermal stresses due to electrical discharge machining. Int J Mach Tools Manuf 42:877888

8. Ghanem F, Braham C, Fitzpatrick ME, Sidhom H (2002) Effect of near-surface residual stress and microstructure modification from machining on the fatigue endurance of tool steel. J Mater Eng Perform 11(6):631-639

9. Ghanem F, Sidhom H, Braham C (2004) Surface integrity and fatigue resistance of spark-machined parts (in French). Ann Chimie Sci Materiaux 29(2):79-91

10. Cusanelli G, Hessler-Wyser A, Bobard F, Demellayer R, Perez R, Flukiger R (2004) Microstructure at submicron scale of the white layer produced by EDM technique. J Mater Process Technol 149:289-295

11. Hiong LS, Xiaoping L (2003) Study of the surface integrity of the machined workpiece in the EDM of tungsten carbide. J Mater Process Technol 139:315-321

12. Hasçalýk A, Caldas U (2004) Experimental study of wire electrical discharge machining of AISI D5 tool steel. J Mater Process Technol 148:362-367

13. Grosch J (1989) Einfluß der funkenerosiven Bearbeitung auf das Randgefüge verschiedener Stähle. HTM Härterei-Techn. Mitt 44:290-295
14. Tadao T, Takeo T (1984) Effect of the electro-discharge machined surface on the mechanical properties - the fatigue strength of carbon steel. Bull Japan Soc of Precis Eng 18(4):341-342

15. Tadao T, Takeo T (1987) Effect of the electro-discharge machined surface on the mechanical properties. Bull Japan Soc Precis Eng 21 (1):70-71

16. Kisuke I, Katsuji T (1988) Fatigue strength of shot penned specimen formed by laser cutting and wire EDM. Bull Japan Soc of Precis Engg 22(3):195-199

17. Casas B, Torres Y, Lianes L (2006) Fracture and fatigue behaviour of electrical-machined cemented carbides. Int J Refract Metals Hard Mater 24:162-167

18. Hocheng H, Lei WT, Hsu HS (2003) Preliminary study of material removal in electrical discharge machining of SiC/A. J Mater Process Technol 63:813-818

19. Obara H, Satou H, Hatano M (2004) Fundamental study on corrosion of cemented carbide during wire EDM. J Mater Process Technol 149:370-375

20. Yan BH, Lin YC, Huang FY (2002) Surface modification of Al$\mathrm{Zn}-\mathrm{Mg}$ alloy by combined electrical discharge machining with ball burnish machining. Int J Mach Tools Manuf 42:925-934

21. Uno Y, Okada A, Uemura K, Raharjo P, Furukawa T, Karato K (2005) High-efficiency finishing process for metal mould by largearea electron beam irradiation. Precis Eng 29:449-455

22. Tsai HC, Yan BH, Huang FY (2003) EDM performance of $\mathrm{Cr} / \mathrm{Cu}-$ based composite electrodes. Int J Mach Tools Manuf 43:245-252

23. Ntasi A, Mueller WD, Eliades G, Zinelis S (2010) The effect of electro discharge machining (EDM) on the corrosion resistance of dental alloys. Dent Mater 26:e237-e245

24. Lee S, Lai J, Huang C (2005) Stainless steel bipolar plates. J Power Sources 145:362-368

25. Yi SM, Jin SH, Lee JD, Chu CN (2005) Fabrication of a highaspect-ratio stainless steel shadow mask and its application to pentacene thin-film transistors. J Micromech Microeng 15:263269

26. Ravi N, Huang H (2002) Fabrication of symmetrical section micro features using the electro-discharge machining block electrode method. J Micromech Microeng 12:905-910

27. Peirs J, Reynaerts D, Verplaet F (2003) Development of an axial microturbine for a portable gas turbine generator. J Micromech Microeng 13:S190-S195

28. Kathuria YP (2006) The potential of biocompatible metallic stents and preventing restenosis. Mater Sci Eng A 417:40-48

29. Sidhom H, Amadou T, Sahlaoui H, Braham C (2007) Quantitative evaluation of aged AISI 316L stainless steel sensitization to intergranular corrosion: comparison between microstructural electrochemical and analytical methods. Metall Mater Trans A Phys Metall Mater Sci 38(6):1269-1280

30. Ben Rhouma A, Braham C, Fitzpatrick ME, Lédion J, Sidhom H (2011) Effects of surface preparation on pitting resistance, residual stress, and stress corrosion cracking in austenitic stainless steels. J Mater Eng Perform 10(5):507-514

31. Braham C, Ben Rhouma A, Lédion J, Sidhom H (2005) Effect of machining conditions on residual stress corrosion cracking of $316 \mathrm{~L}$ SS. Mater Sci Forum (490-491):305-310 